ISSN: 0377-6395
e-ISSN: 2651-4214
DETERİNER HEKİMLER DERNEĞं

DOI: $10.33188 /$ vetheder.692726

Case Report / Olgu Sunumu

\title{
Rapid and successful treatment of a dog with severe generalized demodicosis
}

\author{
Onur KÖSE ${ }^{1, a^{*}}$, Onur OKUR ${ }^{2, b}$ \\ ${ }^{I}$ Burdur Mehmet Akif Ersoy University, Faculty of Veterinary Medicine, Department of Parasitology, Burdur, Turkey \\ ${ }^{2}$ Adress, Pet City Veterinary Clinic, Çayyolu, Ankara, Turkey \\ ORCID: 0000-0002-4021-7429 ${ }^{a}$;0000-0001-7937-4168 ${ }^{b}$
}

\author{
MAKALE BILLGISI / \\ ARTICLE \\ INFORMATION: \\ Geliş / Received: \\ 24 Şubat 20 \\ 24 February 20 \\ Kabul / Accepted: \\ 25 Nisan 20 \\ 25 April 20
}

Keywords:

Amitraz,

demodicosis,

dog,

generalized,

ivermectin

Anahtar Sözcükler:

Amitraz,

demodikozis,

generalize,

ivermektin,

köpek

\begin{abstract}
:
The present study was carried out to treat a dog that was diagnosed as generalized demodicosis with no response to localized demodicosis treatment that spread of the lesions was aggravated and accelerated subsequently. The material of the study consisted of a 10-month old German shepherd dog. Amitraz solution $(0,2 \%)$ as bathing three days a week and spraying for the other days and oral ivermectin tablet $(0,4 \mathrm{mg} / \mathrm{kg})$ three days a week were used together for etiological treatment. Amoxicillin was used to treat secondary bacterial infections for 10 days and vitamin/mineral supplementation and liver preservation were also applied to support general health. Recovery was observed at the end of six weeks both clinically and microscopically, but amitraz bathing and orally ivermectin tablets were continued for another four weeks to prevent any recurrence. As a result; it's considered that, the amitraz $(0,2 \%)$ application as a bathing solution for three days a week and spraying for other days, oral ivermectin $(0,4 \mathrm{mg} / \mathrm{kg})$ three days a week, oral amoxicillin $(400 / 57 \mathrm{mg}$ suspension) daily for 10 days and supportive treatments were successful for the treatment of generalized canine demodicosis in 45 days and no recurrence of infestation were observed for six months follow up. It is also understood that predisposing factors should never be ignored for an effective treatment.
\end{abstract}

\section{Şiddetli generalize demodikozisli bir köpeğin hızlı ve başarılı tedavisi}

ÖZET:

$\mathrm{Bu}$ çalışma; klinikte lokalize demodikozis tedavisine cevap alınamayan ve daha sonra lezyonların şiddetlenerek yayıldığı ve generalize demodikozis teşhisi konulan bir köpeğin tedavi edilmesi amacıyla gerçekleştirilmiştir. Çalışmanın materyalini 10 aylık bir Alman çoban köpeği oluşturmuștur. Etiyolojik sağaltım amacıyla \%0,2'lik amitraz solüsyonu haftada üç gün banyo, diğer günler sprey şeklinde ve ivermektin tablet $(0,4 \mathrm{mg} / \mathrm{kg})$ haftada 3 gün birlikte kullanılmış, ikincil bakteriyel enfeksiyonlara karşı ilk 10 gün oral amoksisilin ve genel sağlığı destekleyici olarak da vitamin/mineral takviyesi ile karaciğer koruyucu uygulanmıştır. Hem klinik görünüm ve lezyonlar hem de etkenlerin tamamen eliminasyonunun mikroskobik olarak tespiti açısından altı hafta sonunda iyileșmenin tamamlandığı gözlenmiș ancak nükslerin önlenmesi amacıyla amitraz banyosu ve ivermektin tablet uygulamaları dört hafta daha sürdürülmüştür. Sonuç olarak; \%0,2'lik amitraz haftada üç gün banyo ve diğer günler için püskürtme şeklinde, ivermektin $(0,4 \mathrm{mg} / \mathrm{kg})$ haftada üç gün oral, amoksisilin $(400 / 57 \mathrm{mg}$ ) süspansiyon) 10 gün boyunca oral ve genel destek amaciyla vitamin/mineral uygulamaları şeklindeki tedavi protokolü, şiddetli bir generalize kanin demodikozis vakasında 45 gün gibi bir sürede başarı sağlamış ve hastanın takip edildiği altı aylık dönemde her hangi bir demodektik uyuz nüksü gözlenmemiştir. Ayrıca etkili bir demodikozis tedavisi için predispoze faktörlerin asla göz ardı edilmemesi gerektiği de bir kez daha anlaşılmıştır.

How to cite this article: Köse O, Okur O: Rapid and successful treatment of a dog with severe generalized demodicosis. Veteriner Hekimler Dernegi Dergisi, 91(2): 176-181, 2020, DOI: 10.33188/vetheder.692726 


\section{Introduction}

Demodicosis is a parasitic skin disease that may manifest itself as localized or generalized forms in various animals, including humans and especially in dogs. Demodex species can be found in hair follicles and sebaceous glands of healthy animals without showing any pathogenic effects but if the immune system becomes suppressed for any reason, this parasitic mite can rapidly multiply, spread and cause various skin lesions and even may result in death in severe cases (20). Generalized canine demodicosis is usually seen in pustular form complicated with staphylococcal pyoderma and is characterized by the spread of multifocal, erythematous crustacean macules and partial alopecia $(10,20)$. It is thought that various predisposing factors such as malnutrition, stress, hormonal changes, estrus, pregnancy, giving birth, age, genetics, and short hair structure are often effective in occurrence of the disease (20). Diagnosis is made by observing adult or other development stages of mites in microscopic examination of deep skin scraping samples taken from affected areas (16). Generally; drugs like amitraz, ivermectin, milbemycin oxime, moxidectin, imidacloprid, doramectin $(10,15,18)$, fluralanel $(8,14)$, afoxolaner $(2,4)$ and sarolaner $(11)$ can be used for etiological treatment. In addition, predisposing factors also should be determined and eliminated in order to have success to treat the disease $(20,21)$.

The aim of the present study is to achieve an effective treatment as soon as possible by applying an amitraz and ivermectin combined treatment protocol and improving living conditions. The drugs used in the present study are already in use for treatment of canine generalized demodicosis but the protocol is newly designed for the present case.

\section{Case Story}

The material of the present case consisted of a 10-month old German shepherd dog of Gendarmerie Horse/Dog Training Center (JAKEM) Command in Nevşehir. In the dog's story; it was learned that, a few-week treatment with daily nitrofurazone and silver sulphadiazine application and intramuscular biotin injection applied to treat alopecia and dandruff in the facial region, but the lesions spread and aggravated without any improvement (Figure 1).

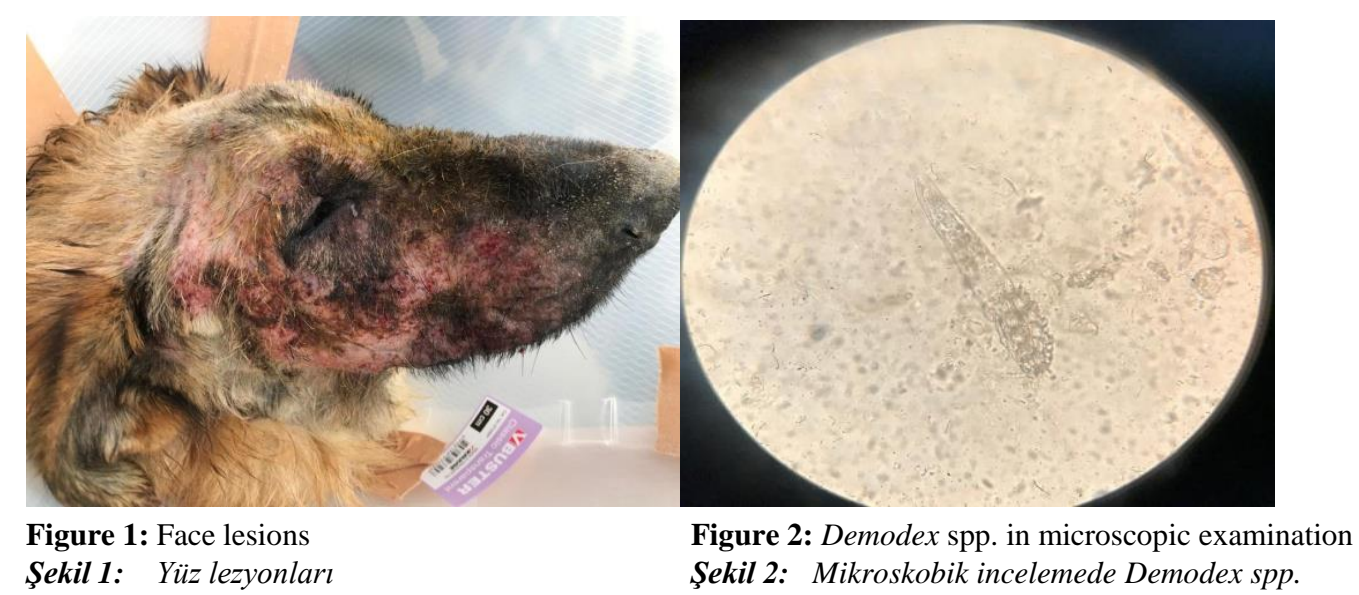

Thereafter, it was diagnosed as localized demodicosis after Demodex spp. adults were determined in the microscopic examination of skin scraping samples (Figure 2). The dog did not respond to two weeks of treatment of cleaning the lesions daily with amitraz $(0,2 \%)$ and subcutaneous injection of ivermectin $(10 \mathrm{mg} / 50 \mathrm{~kg})$ once a week. On the contrary, it was observed that symptoms such as alopecia, scabbing, dandruff, itching, erythema spread all over the body and the case has been exacerbated and generalized and also the dog got severely weak (Figure 3). At this point, it was learned that the housing conditions of the dog were unhealthy (heating, ventilation and cleaning 
failures) and that the food was inadequate and poor in quality. The faecal sample of the dog was examined for endoparasites but no adult or development stages of any parasite were determined.

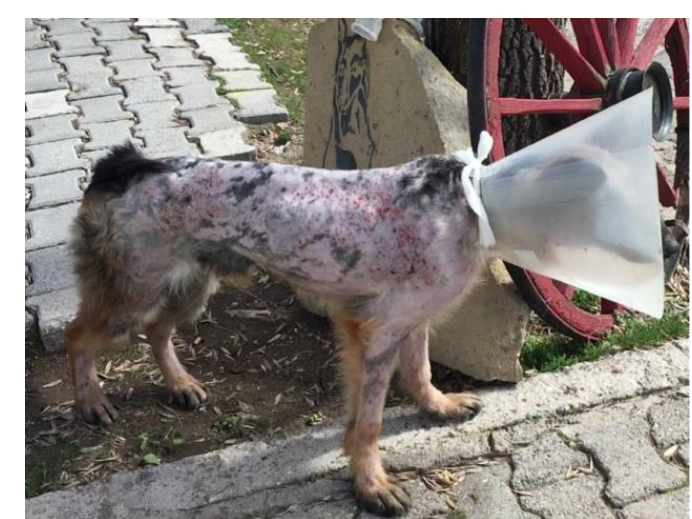

Figure 3: Body lesions before amitraz bathing applications Şekil 3: Amitraz banyo uygulamaları öncesi vücut lezyonları

According to the new treatment protocol established; firstly, the whole body was shaved and wound shells were cleaned (20). For etiological treatment; amitraz (0,2\%) was administered for three days a week (at least 60 minutes for every application) to the whole body as a bathing solution (Figure 4), the other days as spraying and ivermectin $(0,4 \mathrm{mg} / \mathrm{kg}$ ) was administered as an oral tablet for 3 days a week. For the first 10 days, daily $5 \mathrm{cc}$ amoxicillin $(400 / 57 \mathrm{mg}$ ) suspension was administered orally against secondary bacterial infections. As supportive treatment vitamin and mineral complex was used between 1-10. and 20-30. days and also liver supplement was used once a week during the whole treatment period. In addition, instead of food that was observed to be low in nutrition, the dog started to be fed with high-quality food, transferred to a healthier and hygienic shelter in terms of heating and ventilation. Also he was taken out of the shelter for a few hours each day for sunbathing and socializing.

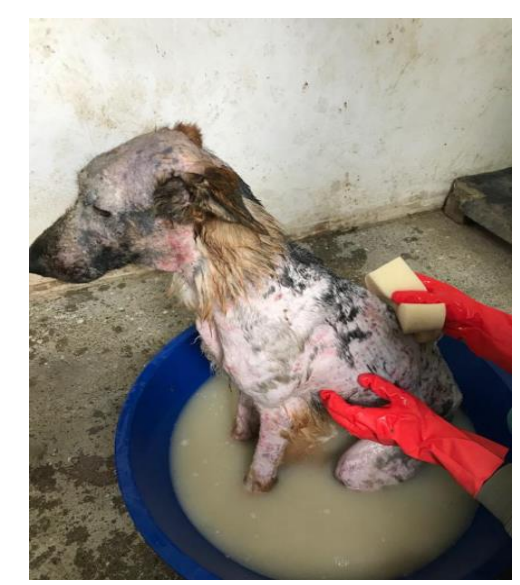

Figure 4. Amitraz bathing application Şekil 4. Amitraz banyo uygulamast

It has been observed that the clinical symptoms diminished day by day, while the skin gained a healthy appearance and the brightness of the coat increased (Figure 5). 


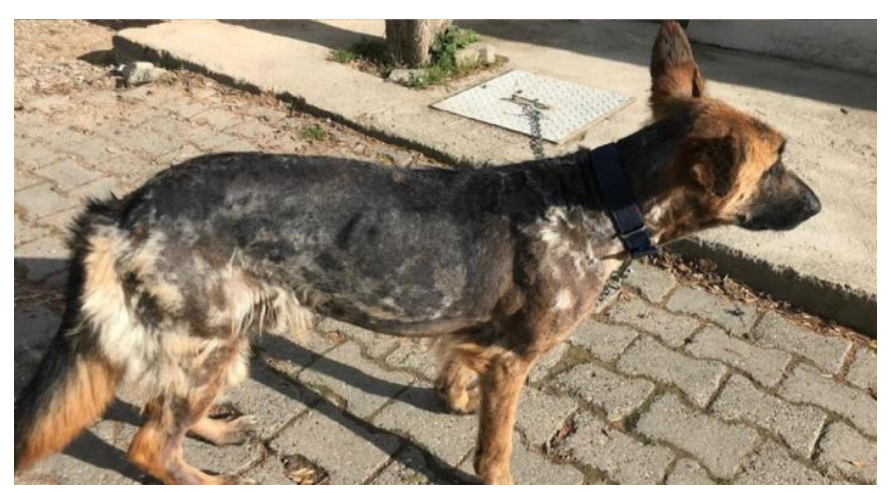

Figure 5: 30th day of treatment

Şekil 5: Tedavinin 30. günü

In order to observe the efficacy of etiologic treatment, deep skin scraping samples taken from various parts of the body for every 15 days (21), were examined microscopically and no adult or development stage of Demodex spp. was found on the 45th day. Despite complete recovery on day 45 both clinically and microscopically, amitraz and ivermectin were continued for another month to prevent recurrence of infestation (20) and treatment was terminated as the skin scraping samples found to be negative on the 60th (Figure 6) and 75th days (Figure 7). Also the weight gain of the dog was monitored during the treatment period; he was $25 \mathrm{~kg}$ on the 6th day and $35 \mathrm{~kg}$ on the 75th day of treatment. No signs of recurrence were observed during the six-month post-treatment period.

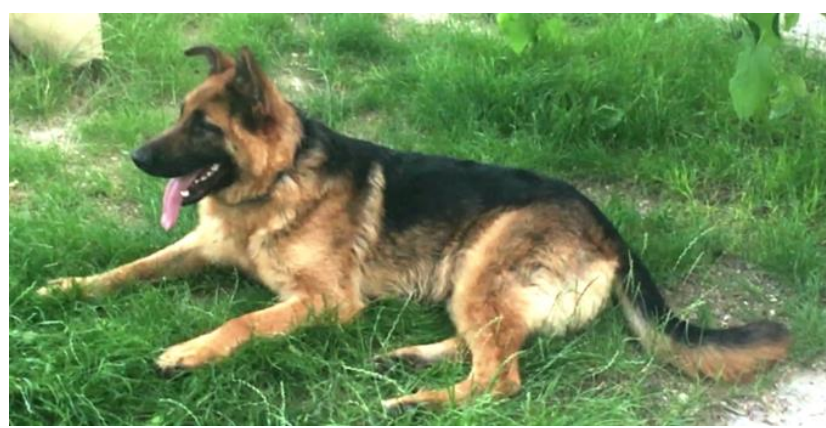

Figure 6: General view on 60th day Şekil 6: 60. günde genel görünüm

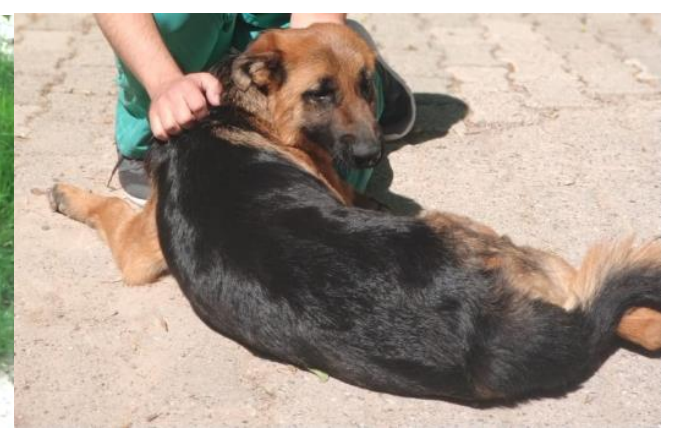

Figure 7: General view on 75th day Şekil 7: 75. günde genel görünüm

\section{Discussion and Conclusion}

In cases of canine demodicosis; drugs and treatment protocols may vary according to predisposing factors, severity of the disease, to be localized or generalized, symptoms, secondary bacterial infections, dog's age, general health status, living conditions etc. and a comprehensive approach is required for effective treatment of generalized form $(1,15,20,21)$. The use of amitraz is recommended as a bathing solution once a week or two weeks $(0,025$ $0,06 \%)$ in various references $(11,15,20,21)$ but there are also different options $(7,9)$. In severe cases with no response, it can be administered twice a week with a concentration of $0,125 \%$ (20). Although the use of ivermectin is once a week $(0,4 \mathrm{mg} / \mathrm{kg})$ by subcutaneous injection, it is not recommended to use as an injection for generalized canine demodicosis $(11,15)$ but oral administration $(0,3-0,6 \mathrm{mg} / \mathrm{kg})$ is recommended daily $(3,6,15)$. In addition, Mueller (17) mentions that the use of oral macrocyclic lactones combined with topical amitraz in patients who do not respond to a single therapeutic agent may be successful in the treatment. In the present case, because the dog was to be treated as soon as possible in order to not interrupt his education, an intensive protocol of amitraz was applied by increasing its dose $(0,2 \%)$ and frequency (bathing three days a week and spraying four days). However, oral ivermectin, which is recommended for daily use, was used at the recommended dose $(0,4 \mathrm{mg} / \mathrm{kg})$, but three days a 
week. The frequency of ivermectin has been reduced because of amitraz is preferred as the primary etiological drug and is already used extensively. Because this is not an experimental study and fast results were needed, two drugs were used together, so it was not possible to evaluate the individual treatment efficacy of amitraz and ivermectin by usage of dose and frequency as this case. However, the use of these two drugs together with protocole given here did not cause any side effects except for a slight sedation of about 30 minutes after amitraz baths (11), but it provided a fast and effective treatment.

In some publications $(5,12,13)$, juvenile and adult forms of the disease are evaluated separately. However, Mueller et al (15) stated that it is not easy to make this distinction for individual cases and that it's more important to eliminate predisposing factors for an effective outcome regardless of age. Also, Scott et al (20) emphasize the importance of nutrition, endoparasitism and vaccination in localized demodicosis. In the present case, localized lesions on the face area of 10-month old dog became generalized and exacerbated despite treatment. Here, adversities in animal care and feeding conditions are seen as predisposing factors and a rapid and successful treatment have been provided by elimination of these factors in addition to the updated treatment protocole. And it seems to be consistent by the comments of Mueller et al (15) and Scott et al (20).

Generalized demodicosis is considered as the most patient skin disease that a veterinarian can treat $(20,21)$. One of the most important reasons for treatment failure is that animal owners want to stop treatment early because of clinical improvement is often observed before the complete elimination of the mites. For effective treatment, the protocol should be continued without any interruption until the end (20,21). Another important issue for treatment success is the elimination of various stress factors suppressing the immune system, that are effective in the emergence and aggravation of the disease $(12,15,19,20)$. Improving the dog's housing and feeding conditions both have a positive effect on the treatment process. Dogs with generalized demodicosis under one year of age may not always need antiparasitic treatment, and that more than 30-50\% of these cases can heal spontaneously, but mostly for dogs in a house environment (20). In the present case; the dog does not live in a house environment and because of the unfavorable living conditions, localized lesions started to become aggravated and generalized despite treatment. On the other hand, conditions, especially the feeding and housing were improved as much as possible and the treatment process was continued without interruption so that a successful treatment was achieved.

As a result; it's considered that, the amitraz $(0,2 \%)$ application as a bathing solution for three days a week and spraying for other days, oral ivermectin $(0,4 \mathrm{mg} / \mathrm{kg})$ three days a week, oral amoxicillin (400/57 $\mathrm{mg}$ suspension) daily for 10 days and supportive treatments were successful for treatment of generalized canine demodicosis. It is also understood that predisposing factors should never be ignored for an effective treatment.

\section{References}

1. Arsenovic M, Pezo L, Vasic N, Ciric R (2015): The main factors influencing canine demodicosis treatment outcome and determination of optimal therapy. Parasitol Res, 114 (7), 2415-2426.

2. Beugnet F, Halos L, Larsen D, de Vos C (2016): Efficacy of oral afoxolaner for the treatment of canine generalised demodicosis. Parasite, 23 (14), 1-8.

3. Chansiripornchai P, Chansiripornchai $\mathbf{N}$ (2008): Treatment of generalized demodicosis in a dog using oral ivermectin. Indian Vet J, 85, 315-316.

4. Chavez F (2016): Case report of afoxolaner treatment for canine demodicosis in four dogs naturally infected with Demodex canis. Int J Appl Res in Vet M, 14 (2), 123-127.

5. Duclos DD, Jeffers JG, Shanley KJ (1994): Prognosis for treatment of adult-onset demodicosis in dogs: 34 cases (1979-1990). J Am Vet Med Assoc, 204 (4), 616-619.

6. Fondati A (1996): Efficacy of daily oral ivermectin in the treatment of 10 cases of generalized demodicosis. Vet Dermatol, 7 (2), 99-104.

7. Fourie J, Dumont P, Halos L, Beugnet F, et al., (2013): Efficacy of a topical application of Certifect ${ }^{\circledR}$ (fipronil $6.26 \% \mathrm{w} / \mathrm{v}$, amitraz $7.48 \% \mathrm{w} / \mathrm{v},(\mathrm{S})$-methoprene $5.63 \% \mathrm{w} / \mathrm{v})$ for the treatment of canine generalized demodicosis. Parasite, 20, 46. 
8. Fourie JF, Liebenberg JE, Horak IG, Taenzler J (2015): Efficacy of orally administered fluralaner (BravectoTM) or topically applied imidacloprid/moxidectin (Advocate $\left.{ }^{\circledR}\right)$ against generalized demodicosis in dogs. Parasites\&Vectors, 8, 187.

9. Fourie LJ, Kok DJ, Du Plessis A, Rugg D (2007): Efficacy of a novel formulation of metaflumizone plus amitraz for the treatment of demodectic mange in dogs. Vet Parasitol, 150 (3), 268-274.

10. Ihrke PJ (2005): Canine and feline demodicosis. 279-280. In: Proceeding of the NAVC North American Veterinary Conference, Orlando, Florida, USA.

11. Koch SN (2017): Dermatology details, updates on the management of canine demodicosis. TVP J, January/February, 77-85.

12. Lemarie S, Hosgood G, Foil CS (1996): A retrospective study of juvenile and adult-onset generalized demodicosis in dogs (1986-1991). Vet Dermatol, 7, 3-10.

13. Miller WH, Scott DW, Wellington JR, Panic R (1993): Clinical efficacy of milbemycin oxime in the treatment of generalized demodicosis in adult dogs. J Am Vet Med Assoc, 203 (10), 1426-1429.

14. Morita T, Momota Y, Mori A, Oda H, et al., (2018): Successful treatment of refractory demodicosis and transient papules with a single dose of fluralaner in a dog with uncontrolled severe endocrine disease. J Vet Med Sci, 80(4), 672-675.

15. Mueller RS, Bensignor E, Ferrer L, Holm B (2012): Treatment of demodicosis in dogs: 2011 clinical practice guidelines. Vet Dermatol, 23, 86-e21.

16. Mueller RS, Bettenay SV (2010): Skin Scrapings and Skin Biopsies. 368-371. In: Ettinger SJ, Feldman EC (Eds), Textbook of Veterinary Internal Medicine, Philadelphia, PA, WB, USA, Saunders.

17. Mueller (2012): An update on the therapy of canine demodicosis. Appl Dermatol, April, 34, E1-4.

18. Murayama N, Shibata K, Nagata M (2010): Efficacy of weekly oral doramectin treatment in canine demodicosis. Vet Rec, 167, 63-64.

19. Plant JD, Lund EM, Yang M (2011): A case-control study of the risk factors for canine juvenile-onset generalized demodicosis in the USA. Vet Dermatol, 22 (1), 95-99.

20. Scott DW, Miller WH, Griffin CE (2001): Muller \& Kirk's Small Animal Dermatology. 6th ed., Saunders, Philadelphia, W.B, USA.

21. Singh SK, Kumar M, Jadhav RK, Saxena SK (2011): An update on therapeutic management of canine demodicosis. Vet World, 4(1), 41-44. 